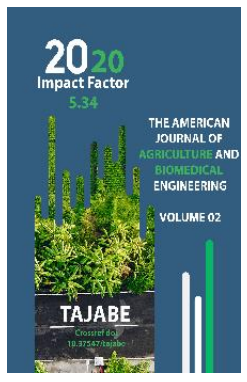

Copyright: Original content from this work may be used under the terms of the creative commons attributes 4.0 licence.

\section{Coniferous Diseases In The Andijan Region}

\author{
Nodira Kamiljanovna Siddikova \\ Senior Lecturer, Department Of Plant Protection, Faculty Of Plant Protection, Agrochemistry \\ And Soil Science, Andijan Institute Of Agriculture And Agrotechnologies, Uzbekistan \\ Mukaddam Kamiljanovna Mirzaitova \\ Department Of Plant Protection, Faculty Of Plant Protection, Agrochemistry And Soil Science, \\ Andijan Institute Of Agriculture And Agrotechnologies, Uzbekistan
}

\title{
ABSTRACT
}

The article provides data on the composition of diseases of decorative coniferous crops in the Andizhan region. In total, 11 species of micromycetes were identified. In the nursery, during the lodging of seedlings, species of the river were noted. Fusarium: Fusarium oxysporum Schlecht. and F. solani (Mart.) Sacc., Verticillium dahlia Klebn. By the frequency of occurrence, Fusarium blight was noted much more often. Lodging of seedlings was also caused by Pythium debaryanum Hesse.

Among the diseases of adult plants, we have identified - rust juniper (exc. - Gymnosporangium confusum Plowr.), defeat of needles (phomosis, rust), shoots and branches (diplodiosis, phomosis). drying of needles and juniper shoots and black needles (Hormiscium pinophilum (Nees.) Lind., Fumago vagans Pers.).

\section{KEYWORDS}

Decorative coniferous crops, fungal diseases, nursery, lodging of seedlings, fusarium, rust, needles lesions, black needles.

\section{INTRODUCTION}

Improving the ecological state of the environment is one of the most pressing problems of cities and megacities. Much attention in ornamental plant growing is paid to conifers. Currently, conifers are one of the main species of green building in Uzbekistan. The high artistic and aesthetic expressiveness 
of conifers makes them indispensable in landscape compositions.

In addition, conifers, characterized by high phytoncidal activity, perform sanitary and hygienic functions in urban plantings, contributing to the formation of microclimatic conditions favorable for humans. This explains the high popularity of conifers and shrubs in green building.[1]

In Uzbekistan, diseases of ornamental treeshrub species have practically not been studied before. In studies carried out in connection with the development of the Golodnaya Steppe, A. Gogolev (1971) identified 152 species of micromycetes on tree and shrub plantations. Lodging of coniferous seedlings in nurseries of Uzbekistan was studied by E. An (1974), she noted 22 species of pathogens of fusarium and verticillary wilt. Sh. Kamilov (1991) studied diseases of tree species in the Botanical Garden of the Academy of Sciences of the Republic of Uzbekistan. In 2018, at the Institute of Botany of the Academy of Sciences of the Republic of Uzbekistan, Zh. Sherkulova defended her dissertation work on causative agents of fungal diseases of ornamental shrubs and trees in the conditions of the Kashkadarya region.

In total, 117 species from 39 genera of micromycetes were identified on woody plants (Sherkulova, 2018). [2]

Separate data can be found in the mycofloristic works carried out by N.I. Gaponenko (1959), who published the "Essay on the mycological flora of the Amu Darya", where she lists 28 species of fungi noted on tree and shrub vegetation, in 1965 she surveyed the Bukhara region, where 19 species, in 1963 T.S. Panfilova and N.I. Gaponenko (1963) published a monograph "Micoflora of the Angren River Basin" with 47 species, F.G. Akhmedova studied fungi of the spurs of the southwestern Tien Shan (1960), where more than 40 species, and T.K. Rotkevich (1960) noted 21 species on the northern spurs of the Turkestan ridge (Guralash reserve). All these data are given in the publication "Flora of mushrooms of Uzbekistan (1983-1997).[2]

\section{THE MAIN FINDINGS AND RESULTS}

According to the literature data, diseases of ornamental breeds can be divided into diseases of adult plants and lesions of seedlings and seedlings in nurseries. As a result of our own research, 6 diseases were identified and 11 types of fungi that cause certain pathologies were identified. Of these, 5 species from 2 genera are parasitic micromycetes causing root rot (fusarium, pityosis), drying is caused by fusarium and verticillus wilt, 1 species is juniper rust, and 2 species are typical representatives of the epiphytic mycobiota that cause black needles. In the nursery, during the lodging of seedlings, species of the river were noted. Fusarium: Fusarium oxysporum Schlecht. and F. solani (Mart.) Sacc., Verticillium dahlia Klebn. By the frequency of occurrence, Fusarium blight was noted much more often. Lodging of seedlings was also caused by Pythium debaryanum Hesse.[3]

From diseases of adult plants, we have identified - juniper rust (exc. Gymnosporangium confusum Plowr.), Damage to needles (phomosis, rust), shoots and branches (diplodia, phomosis). drying of needles and juniper shoots and black needles (Hormiscium pinophilum (Nees.) Lind., Fumago vagans Pers.).

A study to identify diseases of conifers (juniper, spruce, pine) was carried out in the conditions of the Andizhan region on plantings within the city. The pathologies identified by us on conifers over the observation period (2015-2018) are diverse and have both nonparasitic and infectious etiology.[4,6] 
Sampling (shoots and branches with signs of drying out, roots of seedlings and seedlings) was carried out 2-3 times during the growing season, in spring, summer and autumn. During the initial sampling, information about the species, plant age, growing conditions, and organotopic localization of pathological symptoms were recorded.

The following age categories of conifers were subjected to phytopathological assessment: seedlings (juniper, Crimean pine, ordinary village), seedlings, young plants of juniper, pine, ate 10 to 20 years old.[4,5]

Non-infectious (or non-parasitic) diseases are caused by changes in environmental conditions that disrupt metabolic processes in plants, which leads to pathological changes in tissues and organs. They are not transmitted from plant to plant. Such diseases are caused, on the one hand, by unfavorable ecological conditions for the growth of plants, on the other, by violations of the requirements of agricultural technology. So, harsh soil and climatic conditions (spring and summer droughts, uneven precipitation during the growing season, high gas pollution and dustiness of the air, etc.) negatively affect the survival rate, growth and development of many decorative species of conifers. So, low temperatures in winter and spring frosts cause freezing of the crown and roots, while the needles can acquire a reddish color, become dry, die off, the bark of the shoots cracks. In the spring, during sundial, when the soil has not yet completely thawed and the roots are not functioning, browning and burn of the needles are often observed.[7]

The external symptoms of non-communicable diseases, recorded by us in the course of longterm observations, were varied. First of all, this is a change in the color of the needles (yellowing, browning) and its subsequent falling off, the dying off of the tops of the needles, the death of shoots and their tops, thinning of the crown, weak growth or its absence, cracking of the bark, decay and death of roots. These symptoms can often be confused with manifestations of infectious diseases. The main difference between nonparasitic diseases and fungal diseases is the absence of pathogenic (biotrophic) types of fungi on needles, shoots and trunks. Instead, microscopic analysis reveals saprotrophic fungi (in particular, representatives of the genera Capnodium, Cladosporium, Alternaria, Stemphyllium, etc., as well as the species causing the "mob" needles - Hormiscium pinophilum, Fumago vagans.[3]

The most common non-infectious pathologies of conifers in urban plantings are sunburn of needles, damage to young shoots by early and late spring frosts. Damage to junipers, pine needles and tops of non-lignified shoots of which in some years were damaged by spring frosts. During the mass cultivation of planting material in nurseries, a burn or opal of the root collar of seedlings was sometimes observed, which we noted in the seedlings of Scots pine (Pinus sylvestris L.) and Crimean (P. pallasiana D. Don).[7]

A common violation of the agrotechnology of growing conifers and shrubs, which we often observe in urban conditions, is their incorrect planting, which consists in a strong deepening of the trunk. As a result, the bark decays in the place of its contact with the soil, shoots and needles gradually dry out, and the plant dies. Infectious diseases are caused by pathogenic organisms - fungi, viruses, bacteria, mycoplasmas. They can be passed from plant to plant. The most widespread and accessible for phytopathological study are fungal diseases. In urban conditions, coniferous diseases are of lesser phytopathological significance in comparison with natural forests and afforestation. During the period of research on introduced conifers, we identified 6 diseases and identified 12 species of fungi 
and 2 types of bacteria that cause certain pathologies.[11]

In the nursery, during the lodging of seedlings, species of the river were noted.

Fusariu m: Fusarium oxysporum and F. solani, as well as Verticillium dahlia, when the shoots become lethargic, then die. Fungal organisms penetrate into the vessels of stems and roots and clog them, while releasing toxins.In terms of the frequency of occurrence, fusarium was noted much more often compared to verticillus wilt. Lodging of seedlings was also caused by Pythiumdebaryanum.

In the surveyed plantations, phytopathogenic fungi in some cases caused damage to needles (phomosis, rust), shoots and branches (diplodiosis, phomosis, resin cancer). The bacteria Pseudomonas syringae and Erwinia sp. caused the outflow of exudate along the bark of the juniper. The above pathologies, as a rule, were noted on weakened specimens growing in unfavorable conditions.[10]

Phytopathogenic fungi hyphal Stigmina deflectens and pycnidial fungi Phoma juniperi and Diplodia pinea cause shrinkage of the needles and shoots of juniper. In June, the needles turn pale, lose their juicy color, turn yellow, then become covered with brown spots and dry out along with the ends of the shoots. In the case of phomosis, dark dots appear between the scales of the needles pycnidia with spores. Mushrooms cause the death of the needles of the shoots; in case of strong development, the juniper may die.

Rust appears in the spring, when yellow mucous membranes of the fungus telloid form on the needles. Pathogen - Gymnosporangium confusum.[8]

\section{REFERENCES}

1. Akhmedova F.G. Micoflora of the southwestern spurs of the Tien Shan.
Author's abstract... .diss. Cand. biol. sciences., Tashkent, 1966 - 25 p.

2. Gaponenko N.I. Essay on the mycological flora of the Amu Darya // Materials on plant. deserts and low mountains of Middle Asia. - Tashkent, 1959.

3. Gaponenko N.I. Overview of mushrooms in the Bukhara region. - Tashkent, Science, $1965-114 \mathrm{p}$.

4. Gogolev A. Major diseases of protective forest plantations of the Hungry Steppe. Author's abstract. ... diss. Cand. Biological Sciences, Tashkent, 1971 - 13 p.

5. Gorlenko S.V., Blintsov A.Ya., Panko I.A. Resistance of woody introduced species to biological factors. - Minsk, Science and technology, $1988-183 \mathrm{p}$.

6. Kamilov Sh.G. Micromycetes of vascular plants of the Botanical Garden of the Academy of Sciences of the Republic of Uzbekistan. Diss ... Candidate of Biological Sciences - Tashkent, 1991 - 170 p.the Turkestan ridge)

7. Panfilova T.S., Gaponenko N.I. Microflora of the Angren River basin - Tashkent, 1963 -287 p.

8. Rotkevich T. Materials for the microflora of the former mountain-juniper reserve Guralash (northern spurs of the Turkestan ridge) // Materials of the first coor. Meeting of mycologists from Central Asia and Kazakhstan - Frunze 1960 - p. 108-115. Materials of the first coor. Meeting of mycologists from Central Asia and Kazakhstan - Frunze 1960 - p. 108-115.

9. Sinadsky Yu.V., Korneeva I.T., Dobrochinskaya I.B. and other Pests and diseases of ornamental plants. - M., Nauka, 1982 - 592 p.

10. Flora of mushrooms in Uzbekistan. T. IVIII. - Tashkent, 1983-1997

11. Sherkulova Zh.P. Micromycetes of introduced ornamental shrubs and trees of the Kashkadarya region. Diss ... Candidate of Biological Sciences Tashkent, 2018 -111 p. 